\title{
Marrow cellularity in the diagnosis of polycythaemia
}

\author{
NP LUCIE, GAR YOUNG* \\ From the University Department of Haematology, Western Infirmary, Glasgow G11 6NT
}

SUMMARY Increased marrow cellularity is well recognised in polycythaemia rubra vera (PRV), but its value in the differential diagnosis of polycythaemia is not always appreciated. In 28 patients who had marrow aspiration performed on account of a raised haemoglobin concentration or red blood cell count (RBC), marrow cellularity was assessed subjectively and also measured; a comparison was made with the white blood cell count (WBC), platelet count, presence of splenomegaly and plasma volume (PV). Marrow cellularity, particularly when measured was shown to be the most reliable method of making a positive diagnosis of polycythaemia vera; cellularity of greater than $75 \%$ makes it unnecessary to perform other investigations to exclude secondary erythrocytosis.

The diagnosis of polycythaemia rubra vera (PRV) classically depends on the triad of ruddy cyanosis, splenomegaly and increased red cell mass. ${ }^{\prime}$ However, some $20-30 \%$ of patients lack the clinical features and the diagnosis is then based on the exclusion of causes for secondary erythrocytosis. Increased marrow cellularity has long been recognised as a feature of PRV and two studies some ten years ago emphasised the value of a subjective assessment of marrow cellularity on either sections of bone marrow particles or trephine sections in the diagnosis of PRV. ${ }^{23}$ However, the diagnostic value of increased marrow cellularity is not always accepted, perhaps because cellularity as assessed from marrow smears is not of discriminating value between PRV and secondary erythrocytosis. Thus the polycythaemia vera study group did not include marrow cellularity in their diagnostic criteria for PRV. ${ }^{4}$

In this study marrow cellularity was estimated in bone marrow specimens, taken in the course of investigation of a raised haemoglobin concentration or red blood cell count; the diagnostic value of marrow cellularity was compared with other criteria in common use.

\section{Patients and methods}

The 28 patients in this study consisted of successive patients from June 1975 till November 1978 who had sternal bone marrow examination performed in the

\footnotetext{
*Present address: Medical Research Department, Kanematsu Memorial Institute, Sydney Hospital, Sydney 2000.

Accepted for publication 15 September 1982
}

investigation of a raised haemoglobin concentration or RBC in the peripheral blood. Two additional patients in this period were excluded due to inade- $\overrightarrow{0}$ quate marrow material available for examination. No patients had received radioactive phosphorus or cytotoxic therapy prior to marrow examination.

\section{MARROW SECTIONS}

Sections were prepared from aspirated material; haematoxylin and eosin (HE) and Perls' Prussian blue stains were performed. Marrow cellularity was assessed on the $\mathrm{HE}$ sections using a random point grid inserted into the microscope eyepiece; 200 points were assessed by each of two observers. Points overlying haemopoietic tissue were scored and expressed as a percentage of those overlying haemopoietic tissue and fat spaces. Lymphoid tissue was not included. When the two observers disagreed by more than $7 \%$, the slides were reassessed, otherwise the marrow cellularity was expressed as the average of the two scores. Marrow cellularity in all instances was assessed without knowledge of the patient's diagnosis or identity.

Haemoglobin, red cell and white cell counts and absolute values were measured with a Coulter Model S. Platelet counts were estimated by a semiautomated method using a Coulter $\mathrm{ZF}$ after the method of Bull et al. ${ }^{5}$

Plasma volumes were available in all instances; and measured using a radioisotope dilution technique with ${ }^{131}$ I albumin. Directly measured red cell volumes were not always available but when carried out were estimated using ${ }^{51} \mathrm{Cr}$ red cell labelling.

Splenic scans were performed using technetium $\mathrm{Tc}^{99 \mathrm{M}}$. 


\section{Results}

Table 1 shows the peripheral blood values, qualitative assessment of the marrow sections, marrow cellularity, and the final diagnosis. Fourteen patients had PRV, six secondary erythrocytosis and eight reduced plasma volumes with no increase in red cell mass. All patients have now been followed for at least three years and in no instance has the "final diagnosis" had to be changed. In $12 / 14$ patients with PRV a confident accurate diagnosis was made qualitatively though in two instances some doubt existed. Of the other groups the "secondary" nature of the disorder was diagnosed in 13/14 instances (with some reserve in three instances by one observer). The one exception, thought to be most likely, though not definitely PRV by both observers, was initially diagnosed as having PRV but a few months later developed a cerebellar haemangioblastoma.
The mean cellularity of the marrows for the three groups of patients is shown in the Figure. Patients with PRV are clearly distinguishable from the other groups $(p>0.001)$ but those with secondary erythrocytosis and reduced plasma volumes are not significantly different.

Of the 14 patients with PRV, 13 had cellularity greater than $75 \%$ while none of the others had as cellular a marrow. The patient (No 20) with the cerebellar haemangioblastoma had $70.5 \%$ marrow cellularity.

The haematological features of the three groups are summarised in Table 2. Depletion of iron stores was present in almost all patients with PRV, probably accounting for the lower MCV. However depletion was also found in the other groups.

As expected, WBC and platelet count are higher in PRV and clinical splenomegaly is confined to this disorder. Splenic scans were not performed in all

Table 1 Assessment of marrow sections by two observers compared with measurements of marrow cellularity and peripheral blood values; and the final diagnosis in 14 patients with PRV, six with secondary erythrocytosis and eight with reduced plasma volumes

\begin{tabular}{|c|c|c|c|c|c|c|c|c|c|c|c|}
\hline \multirow[t]{2}{*}{$\begin{array}{l}\text { Patient } \\
\text { No }\end{array}$} & \multirow[t]{2}{*}{$\begin{array}{l}\text { Age } \\
(y r)\end{array}$} & \multirow[t]{2}{*}{ Sex } & \multirow[t]{2}{*}{$\begin{array}{l}H b \\
(g / d l)\end{array}$} & \multirow[t]{2}{*}{$\begin{array}{l}R B C \\
\left(\times 10^{12} / 1\right)\end{array}$} & \multirow[t]{2}{*}{$\begin{array}{l}W B C \\
\left(\times 10^{\circ} / 1\right)\end{array}$} & \multirow[t]{2}{*}{$\begin{array}{l}\text { Platelets } \\
\left(\times 10^{\circ} / I\right)\end{array}$} & \multirow[t]{2}{*}{$\begin{array}{l}\text { Spleno- } \\
\text { megaly }\end{array}$} & \multicolumn{2}{|c|}{$\begin{array}{l}\text { Marrow assessment } \\
\text { for PRV }\end{array}$} & \multirow{2}{*}{$\begin{array}{l}\text { Marrow } \\
\text { cellularity } \\
(\%)\end{array}$} & \multirow[t]{2}{*}{$\begin{array}{l}\text { Final } \\
\text { diagnosis }\end{array}$} \\
\hline & & & & & & & & $\begin{array}{l}\text { Observer } \\
I\end{array}$ & ${ }_{2}^{\text {Observer }}$ & & \\
\hline $\begin{array}{r}1 \\
2 \\
3 \\
4 \\
5 \\
6 \\
7 \\
8 \\
9 \\
10 \\
11 \\
12 \\
13 \\
14 \\
15\end{array}$ & $\begin{array}{l}73 \\
71 \\
50 \\
65 \\
73 \\
16 \\
81 \\
60 \\
68 \\
67 \\
72 \\
58 \\
55 \\
56 \\
55\end{array}$ & $\begin{array}{l}\mathbf{F} \\
\mathbf{F} \\
\mathbf{F} \\
\mathbf{F} \\
\mathbf{F} \\
\mathbf{M} \\
\mathbf{M} \\
\mathbf{M} \\
\mathbf{M} \\
\mathbf{M} \\
\mathbf{M} \\
\mathbf{M} \\
\mathbf{M} \\
\mathbf{M} \\
\mathbf{F}\end{array}$ & $\begin{array}{l}20 \cdot 5 \\
17 \cdot 0 \\
17 \cdot 3 \\
16 \cdot 6 \\
15 \cdot 1 \\
18 \cdot 5 \\
20 \cdot 6 \\
17 \cdot 5 \\
18 \cdot 5 \\
23 \cdot 1 \\
21 \cdot 1 \\
22 \cdot 1 \\
22 \cdot 2 \\
19 \cdot 1 \\
19 \cdot 3\end{array}$ & $\begin{array}{l}7 \cdot 8 \\
7 \cdot 1 \\
6 \cdot 2 \\
6 \cdot 9 \\
7 \cdot 1 \\
7 \cdot 2 \\
7 \cdot 5 \\
6 \cdot 4 \\
8 \cdot 0 \\
7 \cdot 2 \\
7 \cdot 6 \\
8 \cdot 8 \\
7 \cdot 3 \\
7 \cdot 8 \\
6 \cdot 2\end{array}$ & $\begin{array}{r}11 \cdot 6 \\
18 \cdot 6 \\
8 \cdot 9 \\
8 \cdot 2 \\
27 \cdot 2 \\
6 \cdot 8 \\
14 \cdot 4 \\
15 \cdot 7 \\
13 \cdot 4 \\
13 \cdot 1 \\
9 \cdot 0 \\
7 \cdot 6 \\
12 \cdot 6 \\
11 \cdot 2 \\
12 \cdot 7\end{array}$ & $\begin{array}{l}645 \\
210 \\
230 \\
240 \\
480 \\
190 \\
250 \\
370 \\
490 \\
305 \\
240 \\
130 \\
355 \\
540 \\
235\end{array}$ & $\begin{array}{l}\text { Yes } \\
\text { Yes } \\
\text { No } \\
\text { No } \\
\text { No } \\
\text { Yes } \\
\text { Yes } \\
\text { No } \\
\text { Yes } \\
\text { Yes } \\
\text { Yes } \\
\text { No } \\
\text { No } \\
\text { No } \\
\text { No }\end{array}$ & $\begin{array}{c}\text { Yes } \\
\text { Yes } \\
\text { Yes } \\
\text { Yes } \\
\text { Yes } \\
\text { ? No } \\
\text { Yes } \\
\text { Yes } \\
\text { Yes } \\
\text { ? Yes } \\
\text { Yes } \\
\text { Yes } \\
\text { Yes } \\
\text { Yes } \\
\text { No }\end{array}$ & $\begin{array}{c}\text { Yes } \\
\text { Yes } \\
\text { Yes } \\
\text { Yes } \\
\text { Yes } \\
\text { ? No } \\
\text { Yes } \\
\text { Yes } \\
\text { Yes } \\
\text { Yes } \\
\text { Yes } \\
\text { Yes } \\
\text { Yes } \\
\text { Yes } \\
\text { ? No }\end{array}$ & $\begin{array}{c}95 \cdot 5 \\
92 \cdot 5 \\
94 \cdot 5 \\
94 \cdot 5 \\
96 \cdot 0 \\
78 \cdot 5 \\
88 \cdot 0 \\
88 \cdot 5 \\
92 \\
71 \\
84 \cdot 5 \\
100 \\
86 \cdot 5 \\
81 \cdot 0 \\
61 \cdot 5\end{array}$ & $\begin{array}{l}\text { PRV } \\
\text { PRV } \\
\text { PRV } \\
\text { PRV } \\
\text { PRV } \\
\text { PRV } \\
\text { PRV } \\
\text { PRV } \\
\text { PRV } \\
\text { PRV } \\
\text { PRV } \\
\text { PRV } \\
\text { PRV } \\
\text { PRV } \\
\text { Secondary } \\
\text { ervthrocytosis }\end{array}$ \\
\hline 16 & 52 & $\mathbf{F}$ & $16 \cdot 7$ & $5 \cdot 7$ & $5 \cdot 6$ & 120 & No & No & ? No & 59.0 & Secondary \\
\hline 17 & 53 & $\mathbf{F}$ & $20 \cdot 5$ & $7 \cdot 1$ & $10 \cdot 9$ & 140 & No & No & ? No & 63.0 & $\begin{array}{l}\text { Secondary } \\
\text { erythrocytosis }\end{array}$ \\
\hline 18 & 59 & $\mathbf{M}$ & $19 \cdot 6$ & $6 \cdot 5$ & $10 \cdot 8$ & 220 & No & No & No & 49.5 & $\begin{array}{l}\text { Secondary } \\
\text { erythrocytosis }\end{array}$ \\
\hline 19 & 64 & $\mathbf{M}$ & $19 \cdot 9$ & 6.9 & $6 \cdot 5$ & 105 & No & No & No & $44 \cdot 0$ & $\begin{array}{l}\text { Secondary } \\
\text { erythrocytosis }\end{array}$ \\
\hline 20 & 63 & $\mathbf{M}$ & $19 \cdot 5$ & $6 \cdot 0$ & $10 \cdot 7$ & 255 & No & ? Yes & ? Yes & $70 \cdot 5$ & $\begin{array}{l}\text { Secondary } \\
\text { erythrocytosis }\end{array}$ \\
\hline $\begin{array}{l}21 \\
22 \\
23 \\
24 \\
25 \\
26 \\
27 \\
28\end{array}$ & $\begin{array}{l}55 \\
58 \\
66 \\
48 \\
47 \\
34 \\
57 \\
37\end{array}$ & $\begin{array}{l}\mathbf{F} \\
\mathbf{F} \\
\mathbf{F} \\
\mathbf{M} \\
\mathbf{M} \\
\mathbf{M} \\
\mathbf{M} \\
\mathbf{M}\end{array}$ & $\begin{array}{l}17 \cdot 3 \\
17 \cdot 7 \\
14 \cdot 4 \\
18 \cdot 1 \\
19 \cdot 8 \\
19 \cdot 1 \\
18 \cdot 6 \\
19 \cdot 4\end{array}$ & $\begin{array}{l}5 \cdot 5 \\
5 \cdot 2 \\
6 \cdot 3 \\
5 \cdot 7 \\
6 \cdot 4 \\
5 \cdot 4 \\
6 \cdot 2 \\
6 \cdot 0\end{array}$ & $\begin{array}{r}8.4 \\
5.3 \\
11.5 \\
8.0 \\
9.5 \\
8.6 \\
8.3 \\
7.9\end{array}$ & $\begin{array}{l}190 \\
145 \\
170 \\
190 \\
200 \\
190 \\
210 \\
220\end{array}$ & $\begin{array}{l}\text { No } \\
\text { No } \\
\text { No } \\
\text { No } \\
\text { No } \\
\text { No } \\
\text { No } \\
\text { No }\end{array}$ & $\begin{array}{l}\text { No } \\
\text { No } \\
\text { No } \\
\text { No } \\
\text { No } \\
\text { No } \\
\text { No } \\
\text { No }\end{array}$ & $\begin{array}{l}\text { No } \\
\text { No } \\
\text { No } \\
\text { No } \\
\text { No } \\
\text { No } \\
\text { No } \\
\text { No }\end{array}$ & $\begin{array}{l}56 \cdot 0 \\
37 \cdot 5 \\
60 \cdot 0 \\
50 \cdot 5 \\
41 \cdot 5 \\
43 \cdot 0 \\
64 \cdot 0 \\
57 \cdot 5\end{array}$ & $\begin{array}{l}\text { Rediced plasma volume } \\
\text { Reduced plasma volume } \\
\text { Reduced plasma volume } \\
\text { Reduced plasma volume } \\
\text { Reduced plasma volume } \\
\text { Reduced plasma volume } \\
\text { Reduced plasma volume } \\
\text { Reduced plasma volume }\end{array}$ \\
\hline
\end{tabular}

Yes = confident diagnosis of PRV.

? Yes = likely diagnosis of PRV.

? No = unlikely to be PRV.

No $=$ PRV excluded. 


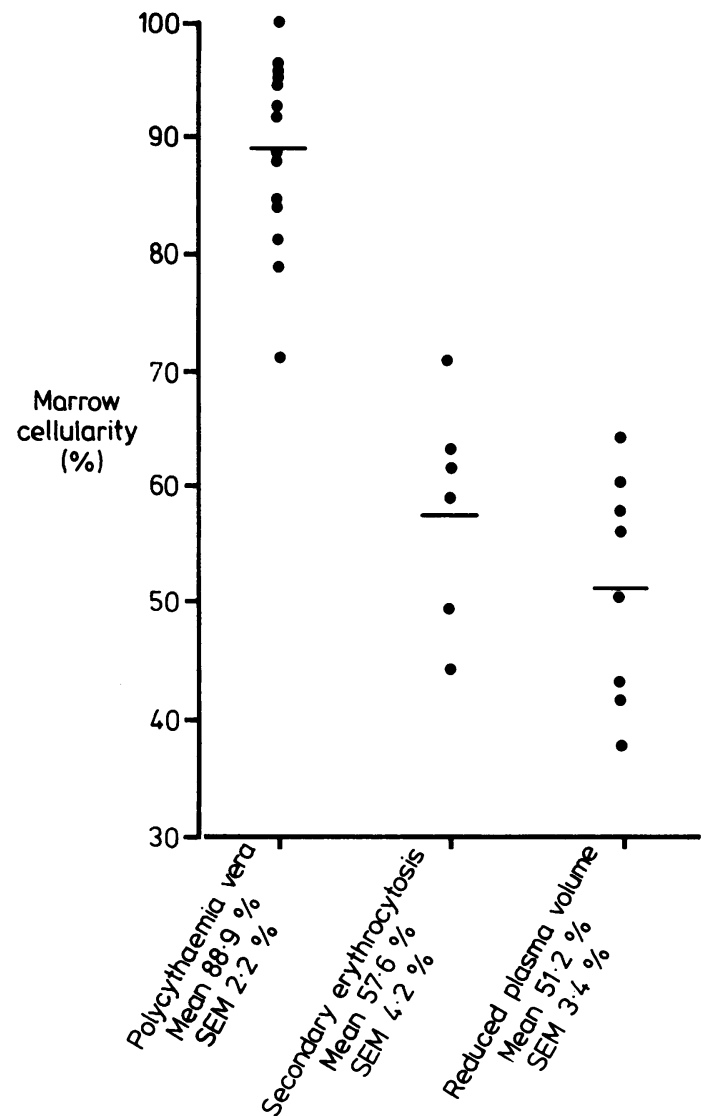

Marrow cellularity in the three groups of patients, showing a clear separation of 13/14 patients with PRV from the other groups. patients. Of eight patients with PRV who had scans, three had clinical splenomegaly and three had lack of splenic enlargement confirmed. One patient had $\stackrel{5}{\rightarrow}$ clinically undetected splenic enlargement and one $\overline{0}$ scan failed to confirm clinical enlargement. Of the three patients in the non-PRV groups who had scans one was thought to have an enlarged spleen while in two a normal sized spleen was confirmed.

Plasma volume estimations were not of value in the diagnosis of PRV. In this disorder the mean PV was $40.0 \mathrm{ml} / \mathrm{kg}$ compared with $35.9 \mathrm{ml} / \mathrm{kg}$ in secondary erythrocytosis and $32.4 \mathrm{ml} / \mathrm{kg}$ in those with reduced plasma volume. In the seven patients with PRV and 8 splenomegaly the mean plasma volume was $40.6 \pm \omega$ $4.7 \mathrm{ml} / \mathrm{kg}$ (mean $\pm \mathrm{SD}$ ) compared with $39.4 \pm$ iv $5.0 \mathrm{ml} / \mathrm{kg}$ in the seven patients without clinically $\vec{\infty}$ enlarged spleens.

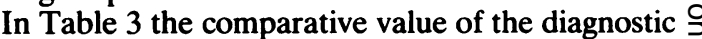
features is assessed. WBC, platelets and presence of $\rightarrow$ splenomegaly are of discriminating value but even $T^{\top}$ taken together they are less discriminatory than marrow cellularity. All four of the PRV patients who lacked a high WBC, platelet count or splenomegaly, had marrow cellularity greater than $75 \%$ (patient Nos $3,4,12,13)$.

\section{Discussion}

Although in general bone marrow trephine is a preferable technique in the myeloproliferative disorders, the cellularity of normal iliac marrow has been shown to decrease in the elderly. ${ }^{6}$ Thus sternal marrow aspirate may be more reliable in the assessment of cellularity and this study has confirmed

Table 2 Comparison of haematological daia (mean $\pm S D$ ) in the three groups of patients

\begin{tabular}{|c|c|c|c|}
\hline Parameter & $P R V$ & Secondary erythrocytosis & Reduced plasma volume \\
\hline $\begin{array}{l}\text { Haemoglobin }(\mathrm{g} / \mathrm{dl}) \\
\text { RBC }\left(\times 10^{12} / 1\right) \\
\text { MCV }(\mathrm{fl}) \\
\text { Absent marrow iron } \\
\text { WBC }\left(\times 10^{9} / 1\right) \\
\text { Platelets }\left(\times 10^{9} / 1\right) \\
\text { Splenomegaly }(\mathrm{clinical}) \\
\text { Plasma volume }(\mathrm{ml} / \mathrm{kg})\end{array}$ & $\begin{array}{c}19 \cdot 2 \pm 2 \cdot 4 \\
7 \cdot 4 \pm 0 \cdot 7 \\
79 \cdot 4 \pm 9 \cdot 4 \\
13 / 14 \\
12 \cdot 7 \pm 5 \cdot 3 \\
334 \pm 152 \\
7 / 14 \\
40 \cdot 0 \pm 5 \cdot 0\end{array}$ & $\begin{aligned} 19 \cdot 2 & \pm 1 \cdot 3 \\
6 \cdot 2 & \pm 0 \cdot 5 \\
91 & \pm 3 \cdot 7 \\
2 / 6 & \\
9 \cdot 5 & \pm 2 \cdot 8 \\
179 & \pm 65 \\
0 / 6 & \\
35 \cdot 9 & \pm 5 \cdot 7\end{aligned}$ & $\begin{array}{c}18 \cdot 1 \pm 1 \cdot 7 \\
5 \cdot 8 \pm 0 \cdot 5 \\
92 \quad \pm 9 \cdot 9 \\
1 / 8 \\
8 \cdot 4 \pm 1 \cdot 7 \\
189 \pm 23 \\
0 / 8 \\
32 \cdot 4 \pm 8 \cdot 5\end{array}$ \\
\hline
\end{tabular}

Table 3 Relative value of WBC, platelets and splenomegaly compared with marrow cellularity in the diagnosis of PRV

\begin{tabular}{|c|c|c|c|c|c|c|}
\hline \multirow[t]{2}{*}{ Final diagnosis } & \multicolumn{2}{|c|}{$W B C$} & \multirow{2}{*}{$\frac{\text { Platelet count }}{>440 \times 10^{9} / l}$} & \multirow[t]{2}{*}{ Splenomegaly } & \multirow{2}{*}{$\begin{array}{l}\text { WBC }>13 \times 10^{9} / 1 \text { or } \\
\text { Platelets }>440 \times 10^{9} / 1 \text { or } \\
\text { Splenomegaly }\end{array}$} & \multirow{2}{*}{$\begin{array}{l}\text { Marrow } \\
\text { cellularity } \\
>75 \%\end{array}$} \\
\hline & $>13 \times 10^{9} / 1$ & $>11 \times 10^{9} / 1$ & & & & \\
\hline $\begin{array}{l}\text { PRV (14 pts) } \\
\text { Not PRV (14 pts) }\end{array}$ & $\begin{array}{l}6 \\
0\end{array}$ & $\begin{array}{l}9 \\
2\end{array}$ & $\begin{array}{l}4 \\
0\end{array}$ & $\begin{array}{l}7 \\
0\end{array}$ & $\begin{array}{r}10 \\
0\end{array}$ & $\begin{array}{r}13 \\
0\end{array}$ \\
\hline
\end{tabular}


earlier work ${ }^{23}$ showing that sections prepared from bone marrow aspiration gives valuable information in the diagnosis of polycythaemia. Only one out of 14 patients with PRV had cellularity less than $75 \%$ while none of the patients in the other groups had such a cellular marrow. In the majority of instances a subjective assessment of cellularity was adequate, but in some patients a quantitative measurement, which could be performed in less than 10 minutes, allowed greater precision.

Of the positive features which are generally considered to have value in diagnosing PRV-the WBC, platelet count, splenomegaly and marrow cellularity, marrow cellularity has been demonstrated to be clearly superior to the others. Even in combination, the other features are not as discriminatory as marrow cellularity and it is noteworthy that four patients with PRV had none of the other features.

It is possible on occasion for PRV to present with an increased red cell mass but no positive feature including increased marrow cellularity to point to the diagnosis; no patient in the present series fell into this category. In this situation, extensive investigation to exclude secondary causes is usually required. However, with this proviso, in the majority of patients a positive diagnosis of PRV can be made and further investigations-for example, intravenous pyelography or blood gases-are not required. Estimation of marrow cellularity on sectioned material is the most valuable method of establishing a positive diagnosis.

\section{References}

' Wintrobe MM. Clinical haematology. Philadelphia: Lea and Febiger, 1974:995.

${ }^{2}$ Kurnick JE, Ward HP, Block MH. Bone marrow sections in the differential diagnosis of polycythaemia. Arch Pathol 1972;94:489-99.

${ }^{3}$ Lundin PM, Ridell B, Weinfield A. The significance of bone marrow morphology for the diagnosis of polycythaemia vera. Scand J Haematol 1972;9:271-82.

${ }^{4}$ Berlin NI. Diagnosis and classification of the polycythaemias. Semin Hematol 1975;12:339-51.

${ }^{5}$ Bull BS, Schneiderman MA, Brecher G. Platelet counts with the Coulter counter. Am J Clin Pathol 1965;44:678-88.

${ }^{6}$ Hartsock RJ, Smith EB, Petty CS. Normal variations with ageing of the amount of haematopoeitic tissue in bone marrow from the anterior iliac crest. Am J Clin Pathol 1965;43:326-31.

Requests for reprints to: Dr NP Lucie, University Department of Haematology, Western Infirmary, Glasgow G11 6NT, Scotland. 